any asides in that direction. The remarks on marriage are more tantalizing than illuminating, and social and political organization-including such headings as crime and law (four paragraphs) and slavery (two paragraphs)-merits only ten pages.

It is not that the author has no interest in the problems of social anthropology; for example, he reports the notable phenomenon-recorded also in other areas - that as the "aggressive intervention" (sic) of the authorities (in this case the American Governor) increased in the daily life of the people, and as they were forcefully moved into "model villages", there was a "withdrawal into the old ways in religion". With the decline of the political importance of the local headmen, the influence of the "mediums" and their ceremonies became more powerful "to the extent that they dominated the social and religious life" of the Bukidnon. But all this is merely stated and not followed up. There are, instead, descriptions of ceremonies concerned with ritual healing and with the fertility of the crops, and there are discussions on the concepts of the supernatural. However, the author seems to have worked through interpreters, and what with the unclear social background and without the backbone of a theory to give the material some coherence, these pages remain unrewarding.

The conclusion strikes a different vein. For, when the author is left with two pages, he reveals that he had in mind all the time "the attempt to account for the peopling of Central and Southern Mindanao": this aim is certainly not disclosed earlier on, nor is it pursued with much vigour.

NUR YaLMaN

\section{VOLTA RIVER PROJECT IN THE GOLD COAST}

$\mathrm{T}$ HE report of the preparatory commission on the Volta River Project set up in 1953 by the United Kingdom and Gold Coast Governments was pub. lished on July 27 as a non-parliamentary paper, and the Secretary of State for the Colonies, Mr. A. T. Lennox-Boyd, said in a written answer in the House of Commons on that day that the report provides evidence of an extremely thorough examination of all the problems to be solved in a project of this magnitude. The main conclusions of the commission are that the project is technically sound and could be carried out successfully; it is not capable of significant improvement from an economic point of view, but the greatest return would be derived by achieving maximum production as soon as possible. The commission further concludes that the project should be competitive in relation to other schemes, provided that the time-table of construction is observed, a sound policy adopted in the employment and provision of living conditions for the labour force, economic stability maintained in the Gold Coast, and that the aluminium companies are satisfied that the internal cost of operating the smelter would be acceptable. The report also considers such factors as the co-ordination of the future development plans of the Gold Coast Government, the maintenance of adequate administrative and technical services, and the level of future world demand for aluminium and future developments in the generation of power from nuclear energy.

As a result of its investigations, the commission considers that the scheme, based on two stages of aluminium production, would cost $£ 184.9$ million (with a capacity of 120,000 tons a year), rising to a total of $£ 231 \cdot 3$ million (with a capacity of 210,000 tons a year) compared with the estimates of $£ 116$ million and $£ 144$ million in 1952 but including also certain additional work. The commission suggests that it would be prudent to allow for a further increase of 40-50 per cent so as to obtain a realistic appreciation of the finances that might be required for the project, which would take about eight years to bring to production. This increase should not make the project less attractive provided world prices move upwards at roughly the same rate. The United Kingdom and the Gold Coast Governments and the aluminium companies have each re-affirmed their interest in the project, though none of them is yet committed to participation. They have agreed that, because of the substantial increase in the estimated capital cost, it is necessary to review both the framework and the method of finance; as the next step, the International Bank is being asked to make a general assessment of the project and to indicate the extent to which it would be willing, in principle, to participate if the two Governments and the aluminium companies reached agreement on the framework.

\section{POLLEN CHEMISTRY}

D LUNDEN, with the citation of some eighty. one references, has given a useful résumé of the literature of pollen chemistry (Grana Palynologica, 1 , No. 2,$3 ; 1956)$. The protein and amino-acid content of different pollen grains has long been of special interest and practical importance, on one hand, to apiarists in search of a pollen substitute in the rearing of bees, and, on the other, to medical investigators interested in the active principle in pollen allergy.

With the development of partition chromatography, considerable advances are now being made in ascertaining both qualitative and quantitative facts regarding the amino-acid content of grains; indeed, all the common amino-acids have now been found to be present in pollens, either bound to protein or in the free state, though some important deficiencies have been reported. As the carbohydrate content of pollen grains is considered to be of less importance from the point of view of bee nutrition, this aspect of pollen chemistry has received rather less attention; but analytical data have been given for the starch, cellulose, pentosan and reducing sugar contents of the pollen of a number of species. Lipides have also been examined.

Studies of the vitamins and hormones of pollen grains have shown that, in general, they are rich in the vitamins of the B group but low in fat-soluble vitamins; some quantitative information relating to a considerable number of vitamins is now available for several species. The evidence indicates pollen to be an exceptionally good source of watersoluble vitamins, for example, of thiamine, riboflavin, pantothenic acid, nicotinic acid and ascorbic acid. CEstrogenic substances have been detected in certain pollens, and also plant growth regulating substances. Pollen enzyme chemistry likewise promises to be a particularly rich field for research. Reference is also made to the pigments, which are chiefly flavonols and carotenoids, and to the inorganic and various miscellaneous constituents. 